\title{
Unintentional social consequences of disorganised marketing of corporate social responsibility: figurational insights into the oil and gas sector in Africa.
}

VERTIGANS, S. 


\title{
Unintentional social consequences of disorganised marketing of CSR: Figurational insights from the oil and gas sector in Africa.
}

\author{
Stephen Vertigans \\ Robert Gordon University, Aberdeen, UK
}

\section{Introducing Corporate Social Responsibility}

Corporate Social Responsibility (CSR) has become a concept that is widely associated with large transnational corporations (TNCS) and increasingly small and medium sized enterprises (SMEs). The concept is contentious with wide ranging debates about intent and impact, not least from critics who perceive CSR to ostensibly be a marketing tool. Before examining some of the current flaws within CSR, it is important to establish how the concept is being applied. There are many definitions. In this paper the World Bank definition is applied, namely that

A company's obligations to be accountable to all of its stakeholders in all its operations and activities. Socially responsible companies consider the full scope of their impact on communities and the environment when making decisions, balancing the needs of stakeholders with their need to make a profit (cited in Duane 2005: 217).

The definition extends corporate responsibilities to the 'triple bottom line' of economics, environment and social or profit, people and planet. In application Blowfield and Frynas (2005) explain that CSR is an umbrella term incorporating: business responsibilities and impacts towards societies and the environment; supply chains and to add value to wider society. Burchell et al (2008) outline that characteristics include: being voluntary; managing externalities; multiple stakeholder orientation; alignment of social and economic (they overlook environmental) responsibilities; practices and values and beyond philanthropy. Nevertheless despite good intentions and often considerable corporate funding, for many companies CSR strategies have limited impacts and lack long term sustainability.

\section{CSR: A critical review}

CSR advocates argue that CSR can improve performance at a number of levels such as staff morale, productivity, human relations, retention and recruitment. Effective CSR can also reduce legal costs and compensation claims while enhancing the appeal of the product or supply.

There is also an argument that CSR is linked to financial performance. Rather than CSR being a waste of shareholders' investments as Friedman (1970) argued in his seminal critique that the corporations only responsibility was to make profit, TNCs with recognised CSR approaches are reported to have higher market share values and levels of profitability. Moreover the resurgence of CSR may well be an indicator that associated activities have an 
impact on the corporate brand. This impact on financial performance and consumer beliefs and confidence in turn enhance reputation and levels of trust (Pfau et al 2008). And within these CSR campaigns, cause related marketing contributes to consumers forming positive attitudes to the advert and then onto the company, brand and product (Nan and Heo 2007, Webb and Mohr 1998).

TNCS CSR image impact connects into international uncertainties, economic competition and rising public awareness and distrust of global corporations that have meant that reputations are also evaluated by institutional and individual investors as balance sheets that extend beyond financial parameters. Hence people and corporate investors such as pension schemes may not be willing to buy shares, banks are not willing to loan money for expansion or consolidation and governments refuse to allocate concessions. In other words, a bad reputation can mean the demise of TNCs; a fact which may have sharpened the enthusiasm of some executives for CSR.

Moreover pragmatically there is an argument that approaches to CSR can provide companies with competitive advantages. When considering strategic approaches, there is an argument that developing policies that connect with core business and stakeholder requirements can be productive. Indeed beyond the immediate confines of TNCs, there are numerous wider social, political, economic and environmental factors which have strengthened demands and commitment to CSR. Globalisation as is often stated, has brought with it opportunities and threats. For instance, oil and gas companies enhanced communications and transportation has opened up new regions for extraction. The same processes have also contributed to their actions being subjected to much greater scrutiny against a backdrop of huge concerns over global warming, environmental disasters, corruption, declining energy supplies and rising prices. Within the oil and gas sector environmental and economic disasters such as those for which Exxon (1989) and Enron (2001) were responsible and the BP led crisis in the Gulf of Mexico (2010) have raised demands for much greater regulation, governance and transparency within the energy sector.

Moreover the structural adjustment programmes that have underpinned international financial transactions and the pervasion into the southern hemisphere have Adanhounme (2011) argues enabled TNCs to negotiate a post-colonial return to, in this instance Africa, on terms to that are to corporates economic advantage. CSR offerings are provided in return for economic penetration to. Nevertheless despite growing evidence about the importance of socially responsible programmes Blowfield and Frynas (2005) argue that companies tend to focus on matters of geography, identity or difference. Failings within development studies are replicated within CSR approaches. Distinctions to be found within the South become the basis for explaining poverty and systemic phenomena is neglected. Ignoring the structural argument reinforces the belief that poverty can be solved by discrete, identifiable actors, whom in this instance would be TNCs. As I explain later this belief is often misplaced resulting in negative outcomes.

Hence CSR content and implementation needs to be adapted to a particular country or region in order to be relevant and legitimate. As Robinson and Tormey (2009: 1396) argue in their discussion of 'global justice' CSR approaches 'display the perspective of a Western, 
white, European or Eurocentric elite, applying the socially contingent "considered" convictions of its own society, complete with the elisions and sanctioned ignorance of these "convictions" in a global context.' In this regard there is a danger that TNCs look to cultivate particular values and practices that are undermined by a sense of moral and cultural leadership. CSR is therefore largely a Western concept although there are differences between USA and Western Europe. In the former, companies have tended to be more proactive in philanthropy. By comparison in Europe, Far East and Australasia there has been greater tendency to address social issues through government policies (Crane et al 2008). Issues can also be regional specific. For example, in Europe CSR is often considered in relation to environmental protection. In the Far East it is about governance and transparency while in countries with long standing issues such as rights of aborigines and blacks, companies are expected to address and uphold rights and to contribute to economic empowerment.

Policies that flow from Western orientated assumptions which aim to be socially responsible may well flounder as soon as they interact with conflicting exogenous factors and processes. Or as Crowson (2009: 105) points out,

The success of investment in public sector capabilities relies in the end on the responses of host countries, and how closely the objectives and interests of the government are aligned with maximising the nation's long term wealth and welfare. Where they are not corporate responses may be frittered away.

Moreover as Utting and Marques (2009) explain, the assumption of functions previously associated with nation-states means that TNCs have an overt presence as political actors and as such become legitimate targets of contestation. This is the 'politics of corporate accountability' which can be connected to Friedman's (1970) argument that CSR is 'undemocratic' with unqualified managers making decisions which lack legitimacy in the 'public interest'. In other others, the 'public' should be making such decisions. For instance, without extensive federal government's engagement in the oil producing region, Shell becomes the de facto government, or representatives of the government. As such expectations, demands and anger is directed the oil company and not the government which is almost detached from local emotions. And as Rwabizambuga (2007) comments, Shell's relationship with the Nigeria government makes it guilty by association.

Through greater exposure, there has been an increase in the levels of familiarity with governance and political arrangements, most notably where they are weak or absent. Hence, the failure of governments to provide security, human rights and what most in the West consider to be basic essentials for life such as healthcare, sanitation and education, places Western TNCs in ambiguous positions. At a basic level, TNCs operating in these vulnerable regions are increasingly expected to intervene.

In essence, therefore CSR as a concept needs to be positioned with local and global processes which they interact with and help shape corporate dynamics. These figurations inform company approaches when determining boundaries for their exogenous commitments. Particular critical attention is placed upon the extent to which approaches 
and principles are designed can suggest as Frankental (2001:23) has argued that 'corporate social responsibility is an invention of PR' or if indeed there are benefits across stakeholders.

\section{CSR as a marketing tool}

Some of the cynicism surrounding CSR stems in part from the belief that related activities and policies are designed to change peoples' perceptions of organisations and/or their products. For instance, Nielsen (2015: 13) suggests that 'practices of CSR can be viewed as a form of advertising. Producing an image of the organisation as being "responsible", "caring", "eco-friendly" or whichever positive label one might produce can be seen as the essential point of CSR'.

Less contentiously Toker (2015: 433) refers to

the increasing attention to corporate practices from consumer and other stakeholder groups, marketing and management scholars have also shown an intense interest in the field of CSR and therefore public relations scholars and practitioners are paying lots of attention to CSR as an integral part of public relations practices.

Marketing ethical issues in order to intertwine profile with values and practices is not however without risks. Claiming to be a responsible organisation can place constraints upon communications allied to ethical considerations. TNC promotional campaigns can thus be challenged on the ethical basis on which they have positioned themselves. Hence marketing criticism can include manipulation, unacceptable social consequences, protection of vulnerable groups and defending the ethically indefensible (Nielsen 2015).

As with other forms of marketing programmes, the effectiveness of related communications, especially to consumers from different backgrounds, remains unclear (Ding 2006, Olsen et al 2003). Moreover as I shall argue later in the chapter, there is also an argument about the ineffectiveness of marketing, particularly when the messages result in unintended negative consequences.

The extension of corporate promotional campaigns into social and environmental spheres that are not immediately directly related to products is typical of,

broader views of marketing [that] see marketing as a philosophy coining the self-understanding of a firm (or organization), and address the firm (or organization) as a market actor and a creator of markets. The domain of marketing thus includes organizations, markets, and marketing systems; and marketing goes beyond market-orientated strategy formation, management, operation and activities ... . Different marketing approaches give rise to different types of marketing problems and 'pre-determine' the type of potential moral failure: Concerning the marketing mix, ethical problems are related to the use of what is called the marketing instruments (expressed in the four Ps- product, price, promotion and place (Haase 2015: 374). 
By adopting CSR as a marketing tool, TNCs are therefore subjected to greater scrutiny and expectations. Promotional campaigns that fail the ethical marketing mix are likely to be subjected to adverse publicity to the detrimental of the corporate reputation. Consequently although some of the cynicism concerning the public relations component of CSR is well founded, marketing has to be grounded within actual policies, practices and intentions. And successful campaigns through the application of marketing ethics 'actively contributes to the understanding and solution of problems well known from CSR and sustainability discourses such as triple bottom line, externalities, globalization, and international public goods' (Haase 2015: 375).

In practice as Guzman and Becker-Olsen (2010: 203) observe,

many companies have responded with more visible investor relations material focussed on CSR initiatives and employee/community engagement programmes. .... Strategic CSR programmes can serve a marketing purpose. In these instances companies may choose to engage in CSR programmes as public relations opportunities, reputational insurance that will help in times of crisis, or brand building.

Again evolving campaigns need to be positioned within changing figurations that contribute to shifting perceptions among key stakeholders. As Banerjee (2008:66) observes the marketing of the environment stems from 'public perceptions of environmental problems along with increased environmental legislation are two key reasons why the environment became an important issue for corporations resulting in the need for companies to "sell environmentalism" in order to be perceived as green'.

For critics such as Beder (2000), environmental emphasis within CSR related policies can be referred to as greenwashing, a process whereby companies manipulate an image of environmental, social and cultural commitments. And within 'greenwashing' image makers connect into contemporary buzzwords such as sustainable development, environmentally friendly and social investment.

Concerns are also raised over the targeting of marketing CSR which often neglects the significance of power dynamics and issues over interpretation. Munshi \& Kurian (2005) argue literature does not acknowledge inequitable distribution among stakeholders and downplays the centrality of the organisational core. In essence, PR is considered by Munshi and Kurian (2005: 514) to be managed through an asymmetrical hierarchy of publics with corporations' public image managed through,

an asymmetric hierarchy of publics: (1) the predominantly Western shareholders; (2) the Western consumer public/the global middle-class consumer; (3) the Western activist public; (4) the vast number of Third World workers who produce the goods for consumption by others; and (5) the even greater numbers of Third World citizens too poor to consume. ... the last two fall below the corporate radar. 
Hence for Munshi \& Kurian (200) the PR focus is upon undercutting protests at level 3 in order to appease consumers and to directly benefit shareholders at the pinnacle of the hierarchy. The disparate levels of priority accorded to stakeholders has led Prieto-Carron et al (2006: 984) to refer to

the lack of discussion about power issues and the dominating discourse of the business case for CSR are particularly salient in relation to stakeholder management ... some stakeholders are often missing ... or physically absent from stakeholders' meetings and forums. They are precisely those in developing countries who do not normally have a voice in society: farmers, children, workers-especially home-based workers and women workers-and all in poor communities who toil under harsh and dangerous conditions exacerbated by the presence of foreign businesses. Even if these groups occasionally have a voice in multi-stakeholder initiatives the most powerful stakeholders continue to shape the issues.

In ranking stakeholders it is not difficult to understand why the financial drivers which result in shareholders are accorded highest status. There are also other factors to be considered including what Prieto-Carron et al (2006: 984) describes as a technical issue, 'namely whether corporations are sufficiently equipped to take on community development roles that require 'soft' social science skills of the kind normally used in aid management. Corporations such as mining companies are often dominated by 'hard science' specialists such as engineers'.

\section{Impact of energy related CSR}

Within the oil and gas sector, there has been increasing attention placed upon CSR (or other terms such as CR, sustainable development, corporate accountability, business ethics, communities, our people etc.). At the level of communication, most national and international companies now include reference to 'responsibilities'. Levels of commitment vary markedly. At the lower level is tokenism that is restricted to web pages and some marquee random acts of philanthropy. The mid approach awards CSR a higher profile within companies. Frynas (2005) points out how this can include add-on measures and technical solutions. Yet there is a restraint upon ambition and on occasion a sense that the increased prominence is in part a consequence of responsibility for responsibility being allocated to corporate communications departments. Such an approach provides support, in some instances unfairly, for those who perceive CSR to be first and foremost a PR exercise or at best part of a calculative assessment which determines whether engagement with CSR is less costly than the reputation damage that may arise without such engagement. Whatever the intentions, the separation of CSR and subservience to Communications (and in some instances $H R$ ) restricts opportunities to incorporate non-financial inputs and outcomes more extensively within decision-making processes. In other words as with CSR approaches more generally contextual environment is neglected.

At the upstanding end of the spectrum are organisations who integrate CSR across their strategic and operational policies and actions. Such companies are inclined to measure the 'triple bottom line' that, explicitly or implicitly, acknowledge, if not measure, economic, 
social and environmental impacts. Understandably impacts are examined through internal controls, rules and bureaucratic procedures. Programmes that extend beyond corporate boundaries and grasp the broader consequences upon communities, governments and global processes are very limited. Consequently CSR strategies largely remain rooted within controlled spheres of activity against a template devised for conditions that rarely apply. At most therefore, 'CSR can work, for some people, in some places, on some issues, some of the time'.

Conversely diverse local forces, pressures and demands will vary markedly across the world and can contradict corporate intentions for consistency and result in challenges in the (de) legitimacy of policies. Such inconsistencies have to be managed and incorporated within socially responsible strategies and interwoven with multinational enterprise. Tuodola (2009) outlines how this can mean very different approaches in different parts of the world. Hence Shell is no longer involved in corruption in Italy, causing oil spills in San Francisco or dumping hazardous waste in Ireland. It is in Nigeria as well as in/direct involvement in human rights abuses, community conflicts and damaging local environments and infrastructures.

These inconsistencies reflect differences which partly stem from energy TNCs operating within different legal frameworks of nation-states. Clearly operating within the law provides (some) legitimacy. Yet sustaining the legitimacy in locations with regulatory gaps in coverage and/or application is perversely more difficult (Rwabizambuga (2007). Moreover greater global media and civil coverage of many of these regions now extends to regions with limited regulatory coverage and has resulted in greater awareness of oil and gas company misdemeanours.

In regions lacking government authority, legal jurisdiction and consensual politics, companies may have a number of options. To:

a) Seek to extend their remit into geographical political and military areas of responsibility and be subjected to considerable criticism about the imposition of unelected forms of governance;

b) Introduce widespread policies and acts of philanthropy that have little likelihood of success;

c) Restrict ambitions.

In other words, without an accommodating framework which would incorporate, support and strengthen company programmes, corporate reach will be restricted to those areas or enclaves that companies control.

Oil and gas companies are easy targets when criticising implicit and explicit engagement with corrupt regimes. Nevertheless there are occasions when companies have utilised their position to influence constructively public policy. For example, Frynas (2009) outlines the impact of BP upon the Azerbeijan government. Such constructive relationships are not reflective of others such as those where oil and gas production is largely nationalised leaving private companies little power of negotiation. And even in situations where private companies are fully involved in production, governments are frequently the dominant 
partner, able to curtail the commercial activities of even the largest oil companies such as BP, Exxon and Shell. Frynas (2009: 167) observes that the different examples indicate the 'importance of context for the success of CSR initiatives'. Moreover resource extraction creates particular economic, social, political, environmental and cultural problems that other economic sectors do not encounter. Finally Frynas points out that within particular environments greater commitment from oil companies will result in less pressure on the governments such as the Nigerian to provide services. Yet governments typically receive between 70 and 80 per cent of revenues with the remainder accruing to companies.

When summarising oil and gas companies approaches overall emphasis upon CSR related policies and actions has grown. However these are rarely coordinated either within corporate initiatives or with affected communities. Nor are the impacts measured beyond crudities. Moreover by focussing upon short term tangibles such as buildings, discussed below, the processes which contribute to the initial problems are neglected. The impact of CSR approaches will inevitably be restricted and possibly even detrimental. Conversely ambitions have to acknowledge the limitations that stem from restrictions upon corporate aims, resources, capabilities, appropriateness of behaviour and the contexts in which they operate. TNCs need to have a much clearer indication about the causes of the problems they are encountering and the consequences of their actions. Through greater knowledge and understanding of the social and natural environments in which they (might) operate TNCS are able to make better informed risk assessments and thus enhance decision-making. Such insights can be found within figurational sociology. Of particular resonance for this chapter is the concept of unintended consequences.

\section{Figurational framework}

In On the Process of Civilization, Elias (2000) [1939], examines how over centuries individual distinctions and social similarities both shape and are shaped by shifting transformations of human relations and activities. These changes occur within competing power balances and enable insight into the balances between self and social restraints. Figurations develop over generations as more and more groups belong in mutually independent relationships which stem from local through to regional, national and then increasingly across global spheres. Figurations are formed by people 'which connect the psychological with the social, or habitus with social relations' (van Krieken 1998: 49). The figurational conceptual framework which Elias initiated provides a basis on which to illuminate underlying processes of social development with dynamics that incorporate local, regional, national and increasingly global levels with self and social identifications and transformations. Such relations are embedded in networks or webs of interdependence that require consideration of the needs and requirements of others. Levels of consideration are determined in part by power ratios within functional democratisation allied to levels of knowledge and understanding about other people and groups within the webs of interdependence. Relatively marginalised groups who have less influence within figurations range from women and ethnic minorities through to communities and nation-states, most notably within the southern hemisphere. Figurations with high levels of asymmetrical power relations can enable those in control to exercise more rationally than more symmetrical power ratios (Dunning and Hughes 2013: 47). However the extent of control is influenced by degrees of influence and related to power balances. Moreover as I argue below, greater disparities of power are often 
accompanied by weaker levels of mutual consideration which can result in tensions and ultimately conflict.

This power imbalance is prevalent between TNCs and communities with the former having greater control and influence within inequitable levels of interdependence. The imbalance stems from the power to invest exceeding the power of employment and cooperation that communities possess. However this power imbalance is not static, people can withdraw services or refuse to buy them which enables enhanced power and control. Better organised groups and more involvement within widening chains of interdependence result in more even forms of reciprocal dependence. Conversely, as I explain below, in relation to the oil and gas sector, weak levels of consideration can contribute to ill-formed decisions that result in rising communal tensions which are the unintended consequences of CSR approaches.

Within social science the concept of 'unintended consequences' has been applied since the eighteenth century European physiocrats, philosophers and economists (van Krieken 1998: 51). Arguably the most prominent contribution remains Adam Smith's 'hidden hand of the market' whereby the outcome of self-interested actions of individuals was an unintended regulating economic order. The concept was to feature prominently in classical sociology most notably in Karl Marx's prophecy that that the ruling class would create the conditions for their downfall fits neatly as a unintended consequence. Ironically the same principle could be applied to Marx prediction and the possibility that the unanticipated outcome was that the bourgeois were forewarned and actively changed the course of history through sufficiently shifting power and economic differentials in order to better control levels of dissension and unrest.

The concept was revitalised in the 1950s when Robert Merton differentiated between selffulfilling and self-defeating prophecies. However Merton (1967) considered such consequences to be relatively rare. This is borne out by his example of the collapse of the American Last National Bank (1932) which was caused by false rumours about the bank's trading position. On hearing the rumour customers quickly sought to withdraw their funds which the bank was ultimately unable to meet the demand for cash. The fears became reality. Although Merton's analysis is fascinating the above example is indicative of his underpinning sociological perspective, namely that targeted institutional controls would have prevented the collapse of the bank. Hence self-fulfilling prophecies could be avoided through deliberate rational action.

By comparison with the exceptionalism of Merton's approach, for Norbert Elias (2000), as the above outline of 'civilising processes' suggests, unplanned social development and processes are integral both to long term transformation and everyday activities. Of course individuals, groups, communities, nation-states and businesses all plan to varying degrees and are able to achieve intended outcomes. Nevertheless their knowledge about the surrounding figurations and habitus can only be partial, they cannot know precisely how their actions, policies and procedures will impact upon the plans of others, indeed they may not even be aware of their existence. Through this insight Elias re-positions unintended consequences into the essence of social relationships and activities. Drawing upon an analogy of a stone dropped into a pond shows that one can see ripples on the surface that 
undulate from the point of entry. Similarly within complex figurations and dense patterns of mutual interdependence the outcomes of individual or social actions can be visible. However, as with the pond and the underwater waves that the stone generates, the observer cannot witness the impact once they reverberate beyond their immediate controlled environments. Goudsblom (1977: 149) extends Merton when pointing out that 'yesterday's unintended social consequences are today's unintended social conditions of intentional human actions'. The implications of this both for sociologists and TNCs are immense. The interwoven 'blind' processes bind together larger and larger numbers of people in ever increasingly complex and extensive figurations that stretch from locales to global networks. These insights challenge the predictive capabilities of social scientists, particularly when foresight is based upon snapshots of contemporary slivers of social life which increasingly are indicative of sociological analysis.

To help deal with the complications and uncertainties Elias proposed that sociology should focus more upon reality-congruent knowledge that is formed around concepts which individuals apply with high levels of detachment. These terms are more adequate for understanding and explaining experiences. Alertness to the possibility of unintended consequences must be integral. For TNCs a first step would be to acknowledge that they are not fully in control of the consequences of their actions while striving to remain objectively detached, applying concepts which have shared use in thinking, speaking and acting. With reality congruence often beyond the capabilities of sociologists, the financial pressures facing TNCs and distinct socialising experiences highlight how 'value-congruence' influences CSR programmes and their particular views on development. And as we shall discover, CSR programmes are often underpinned with Western values and ideals within frameworks for development which express how people or communities should develop. And in this they replicate what Elias (1978: 147) observed that 'perhaps the real reason why social development remains so puzzling to us is that our efforts are directed less towards understanding and explaining what actually happens and to making a diagnosis, than towards making a hopeful prognosis'. Hence CSR interventions can be considered to be based more upon 'value-congruent' ideas that reality-congruent. Changing employment patterns which has seen greater participation of social scientists may contribute to more reality congruent knowledge that is detached from corporate subjective experiences and shared with indigenous and academic local and international communities.

\section{CSR's unintended consequences}

Applying the concept of unintended consequences to CSR activities draws out two interrelated problematic areas within TNC approaches:

First, as discussed below, is the lack of reality congruence which stems in large part from a lack of knowledge about the locations and peoples most affected;

Second, relates to the over-promotion or misplaced marketing that has resulted in shattered promises and unmet expectations.

For many companies the ineffectiveness of their CSR strategies stems in part from their limited appraisal of the environment or community to which they are establishing new sites 
and businesses and their underlying unfounded expectations. Lauwo and Otusanya (2014) have outlined how broader socio-political, economic and historical structures and global processes which shape CSR approaches tend to be neglected. Energy companies adopt universal goals uncritically. Roberts (2006) observes how contrary to the thorough investigations undertaken by companies into understanding new markets and competitors, little attention is placed upon understanding new work based locations or the impact of their activities upon surrounding communities. Moreover CSR initiatives that are centralised, Barkemeyer (2007) argues, will be less likely to adapt to different contexts.

Although the potential for CSR in alleviating poverty and sustainable development (Idemudia 2009) is increasingly acknowledged, Khan et al (2010) argue the work remains partial, underdeveloped and the impact of post-colonial conditions is neglected. Otherwise 'delusions and disappointment, failures and crimes have been steady companions of development and they tell a common story: it did not work' (Sachs 1992: 1).

One of the consequences of shallow knowledge allied to organisational concentration upon directly controllable outcomes means that the extended consequences of TNCs' activities can be unnoticeable, detached from their cause/s and even discarded. More immediate, visible outputs are however much easier to observe. Hence companies can measure progress by the number of local residents they employ and the health facilities and schools that are built. Gulbrandsen and Moe (2007) point out how companies focus on the 'microlevel' directing actions towards communities in which they operate. These are tangible benefits that stem from organisation's direct control. The dark sides of their CSR policies include the surge in criminal activities that rising income levels can attract, the decline in local industries and businesses whose better staff are recruited by TNCS and the migratory pull of the regions. Local services, including company built hospitals and schools become overwhelmed. Suddenly institutions that were designed to help and improve lives become the sites of contested access and rising tensions. With the rising tensions, companies seek to build or reinforce security in order to protect property, resources and staff. For instance, within the Niger Delta oil companies have retreated into their own compounds surrounded by fences and armed guards. Lacking legitimacy (Idemudia 2009) in the opinion of many locals, and security and legal structures that one would expect from many national governments, TNCs in the Niger Delta are resorting to self contained communities. The cornerstone of this approach is the arrangements they have introduced for their own protection. However this has tended to result in an over-reliance on security arrangements at the expense of interaction and engagement with local communities (Omeje 2006). The physical and psychological divides between TNCs and communities is thus exemplified by the reinforced perimeter fences that are seen to protect the incomers from the local people.

Following this line of argument, a social, business and sustainable environment that is conducive to, and supportive of CSR approaches has to be embedded within surrounding relationships. Frankental (2001: 23 ) asserts that CSR 'can only have real substance if it embraces all the stakeholders of a company' with social and environmental sustainable goals 'embedded across the organization horizontally and vertically'. Similarly Amaeshi (2011) suggests CSR will struggle if in isolation from other complementary institutional configurations. The discourse needs to be situated within broader activities including 
material resources and external factors. Such integration can be achieved through greater consultation and civil engagement in sustainable development and prevention of environmental harm.

Encouraging greater involvement is not without problems, not least surrounding institutional frameworks and preceding perceptions that may restrict levels of participation. For instance, in their attempt to increase levels of participation Total published documents in four languages that were considered to be prevalent within relevant communities. However little or no consideration appears to have been allocated to people whom could not read. In such situations, educated members act as gatekeepers or interpreters, reinforcing their power credentials and existing privileged position which had enabled them to gain a level of education that was not offered to others. Hence the issue of language can reinforce already empowered communities such as men and landowners while excluding underrepresented groups such as women and the landless.

Enhanced levels of detached knowledge could also help to underpin marketing campaigns introducing caution to public relations. Certainly there is a need for realism in corporate promises and programmes and stakeholder expectations. For example, Chevron claim to be 'helping the Angolan people improve their health, education and livelihoods'. Yet in reality Chevron's CSR programmes impact upon a few thousand people at most. Hence they are not helping the 21 million Angolans instead they are helping a fraction. This is not to be overly critical of how the fraction's lives could be improved. Nevertheless what is at best loose wording is within a context of hyperinflation of expectations that surround oil and gas, namely that discovery of large reserves will create both widespread employment opportunities and wealth. National governments, particularly during elections, and oil and gas TNCs must share the blame for the ways in which they have contributed to the promotion of hopes and dreams that they do not have the means of meeting. Therefore, there has to be acknowledgement that TNCs direct impact on poverty and income generation through employment is limited.

Furthermore, CSR public relations initiatives can result in unintended consequences that are contrary to the initial intentions. Support is being provided by TNCs to address fundamental health, social and financial problems which are presented as public relations opportunities. Barkemeyer (2007) outlines how companies tend to develop short projects with high promotional visibility rather than longer-term capacity building initiatives. Again it is easy to understand corporate approaches, particularly in energy producing regions which are increasingly vulnerable to political transformations. Focussing on high profile developments such as digging water wells and building medical facilities that are accompanied by photographs are much more tangible compared with shifts in social relationships, transforming opportunities, enhancing the supply chain and contributing to a burgeoning civil society. At one level, TNCs self-determined power to intervene and transform lives such as Chevron's assertion that they will, with partners, 'identify programmes to promote a better standard of living' can be considered laudable. Nevertheless the reverse is that their interventions are creating and reinforcing stifling barriers.

Drawing upon earlier figurational contributions, these solutions are hopeful prognosis, based on value congruence that often accords both with caricatures of Western solutions 
for hapless victims who are incapable of overcoming problems; perceptions which some of the community demands reinforce. Certainly as Ite (2007) points out, Shell's Community Assistance approach (1960-97) portrayed communities as helpless victims and contributed to a dependency culture. The framing of people as what Banerjee (2008) describes as 'passive recipients of the beneficiaries of development' enables TNCs to be positioned, like the colonialists before them, as providing salvation from famine, HIV/AIDS, corruption and backwardness. In this regard, wider criticism of Western orientated development from a post-colonial perspective is valid. Critics such as Escobar (1995) have argued, in relation to Columbia and can be applied across much of the southern hemisphere, that contemporary problems such as low life expectancy, poor housing and sanitation only became problems within representations of colonialism and campaigns against global poverty. Captured within the poverty net is self-provision. Yet as Shiva (1988) asserts this form of independent living is not poverty yet the ideology of development declares it to be so. On the reverse side within today's narrative self-provision can be considered to be sustainable living, arguably a potential template for addressing environmental mismanagement. Hence the lack of recognised consumption is both the basis for their exogenously declared poverty and their sustainable living.

To again try balance the criticism against a backdrop of a lack of infrastructure and poor social welfare programmes, Alam et al (2010) suggest MNCs can 'have a positive impact in developing countries, especially through corporate social responsibility (CSR) initiatives focusing on sustainable development'. Nevertheless the reality is the short termism of programmes. Although consideration must be given to sustainability of investments, there are multiple examples of the opposite. For instance, Coca Cola funded the building of a hospital in Mozambique and provided equipment. At this point their commitment ended and within a few months the equipment had been sold and building had become living space for the homeless (Hopkins 2007).

In these locations it is more productive to incorporate the different strands of responsibility within a consistent framework rather than destroy indigenous forms through the imposition of Western principles and activities. Local engagement with communities and the incorporation of their ideas and practices will strengthen support for, and durability of, the initiative. Instead the starting point of shallow knowledge allied to organisational concentration upon directly controllable outcomes means that the extended consequences of TNCs' activities can be unnoticeable, detached from their cause/s and even discarded.

\section{Concluding: Way forward}

'A greater current need is for a larger fund of more reality congruent knowledge than is available today about ourselves and the societies we form, that is for knowledge that will increase our capacity to control social processes and events' (Dunning and Hughes 2013: 146).

In the search for more reality congruent knowledge and to reduce the likelihood of problematic unintended consequences, greater familiarity of local conditions can lead to an acknowledgement that other forms of moral principles and voluntary regulation are already embedded within economic enterprises in different contexts. In operating locations 
incorporating different strands of responsibility within a consistent framework can be more constructive than destroying indigenous forms through the imposition of Western principles and activities. Local engagement with communities' habitus and the incorporation of their ideas and practices will strengthen appropriateness and support for, and durability of, initiatives thereby enhancing the often vague corporate intentions. And TNCs can therefore contribute to a more closely defined structured sustainable programme through better informed analysis which acknowledges the validity of some post-colonial analysis and intentions of some development.

Moreover the moral impositions that underpin CSR prescriptions are not inevitable. Amaeshi and Adi (2006: 13) stress that most of its contents 'can be neutrally positioned within the non-market environmental strategy without any moral taints, and without losing its objectives' although I would add that this depends on the objectives. The authors advocate that CSR is reclaimed as neutral management activities.

If companies are to acquire the breadth of knowledge and understanding that would enable better informed decision-making in rapidly transforming regions, they must have employees who can consider deep rooted cultural, economic, environmental, political and social issues and wider processes. In this regard numerous companies now promote CSR associated issues and disseminate related literature. Certainly this helps particular facets of organisational functions but the short duration of the training and narrow focus upon normative behaviour and expectations means that the grasp of wider and interrelated activities and processes is limited. This shallowness is indicative of the ways in which many companies continue to approach CSR and is contributing to ongoing criticism over social and environmental failings and the neglect of more progressive policies. By dividing responsibilities into the domains of finance, social and environment, outcomes are artificially separated rather than part of highly interdependent processes. Thus policies are devised that aim to contribute to social well-being with no recourse to the financial and environmental costs which maybe contradictory. To overcome this requires a multidisciplinary approach that allows for the incorporation of different influences and competing impacts that extend beyond corporate boundaries. By comparison with the hitherto centralised approach, decentralised arrangements are better positioned to identify both what is relevant to stakeholders and local peculiarities which might impair initiatives. Therefore approaches need to consolidate different stakeholders that integrates different expectations and demands (Maon et al 2010). Wider inclusion can be achieved through greater consultation and civil engagement in sustainable development and prevention of environmental harm not least to underpin PR campaigns with messages and impacts which transcend national boundaries.

And by engaging with stakeholders, CSR can be adapted to local needs and demands. In short it has to be context specific. Amaeshi et al (2006: 9) point out that in the instance of Nigeria CSR will be about addressing the,

peculiarity of the socio-economic development challenges of the country (e.g. poverty alleviation, health care provision, infrastructure development, education etc.). They might not necessarily reflect the popular western 
standard/expectations of CSR (e.g. consumer protection, fair trade, green marketing, climate change concerns, social responsible investments etc.

The success of considerable sums of investment in building CSR related capabilities and associated marketing campaigns ultimately relies upon how closely corporate objectives and interests are aligned with those of the national government and indigenous communities. By placing much greater emphasis on finding out what the people want, why they want it and how they would like to achieve the outcomes TNCs investment will be much better positioned to reduce the likelihood of unintended consequences through the achievement of inclusive sustainable development.

\section{References}

Adanhounme, A. (2011) "Corporate Social Responsibility in Postcolonial Africa: Another civilizing mission?" Journal of Change Management, 11(1): 91-110.

Ahmad, A. (1992) In Theory, Classes, Nations, Literatures. London: Verso.

Alam. S.M.S, Hoque, S.S. and Hozen, Z. (2010) "Corporate social responsibility (CSR) of MNCs in Bangladesh: a case study on GrameenPhone Ltd", Journal of Potuakhali University of Science and Technology. Available at SSRN; http://ssrn.com/abstract=1639570.

Amaeshi, K.M., Adi, A.B. C., Ogbechie, Chris and Amao, Olufemi O. (2006). Corporate Social Responsibility in Nigeria: Western mimicry or indigenous influences? Available at SSRN: http://ssrn.com/abstract=896500 (last accessed 11 June 2016).

Amaeshi, K. (2011) 'International Financial Institutions and Discursive Institutional Change: Implications for Corporate Social Responsibility in Developing Economies', Journal of Change Management, 11: 1, 111-128.

Banerjee, S. (2008) 'Corporate Social Responsibility: The Good, the Bad and the Ugly', Critical Sociology, 34(1): 51-79.

Barkemeyer, R. (2007). 'Legitimacy as a Key Driver and Determinant of CSR in Developing Countries'. Paper for the Marie Curie Summer School on Earth System Governance, 28 May6 June.

Blowfield, M. and Frynas, J.G. (2005). Setting New Agendas: critical perspectives of Corporate Social Responsibility in the developing world. International Affairs, 81(3): 499513.

Burchell, J. (ed) 2008. The Corporate Social Responsibility Reader, Abingdon, Routledge. Chakrabarty, D. (2000) Provincializing Europe: Postcolonial thought and historical difference. Princeton: Princeton University Press

Crane, A., Matten, D. \& Spence, L (eds.), 2008. Corporate Social Responsibility: Readings and cases in a global context, Abingdon, Routledge.

Crane, A., 2009. The Oxford Handbook of Corporate Social Responsibility, Oxford University Press.

Crowson, P. (2009) 'Adding Public Value: The limits of corporate responsibility', Resources

Policy, 34: 105-111.

Ding, D. (2006) 'An indirect style in business comunication', Journal of Business and Technical Communication. 20(1): 87-100.

Doane, D. (2005) 'Beyond corporate social responsibility: minnows, mammoths and markets', Futures, 37: 215-29.

Elias, N. (1978) What is Sociology, London: Hutchinson. 
Elias, N. (2000) [1939] The Civilizing Process: Sociogenetic and Psychogenetic Investigations, Oxford: Blackwell Publishers Ltd.

Escobar, A. (1995) Encountering Development: The making and unmaking of the Third World. Princeton: Princeton University Press.

Frankental, P. (2001) Corporate Social Responsibility: A PR invention? Corporate Communications, 6(1): 18-23.

Friedman, M. (1970) The Social Responsibility of Business is to increase its profits. The New York Times, 13, 32-33; 122-26.

Frynas, J.G. 2010. Beyond Corporate Social Responsibility: Oil Multinationals and Social Challenges, Cambridge: Cambridge University Press.

Gandhi, L. (1998) Postcolonial Theory: A critical introduction. Edinburgh: Edinburgh University Press.

Goudsblom, J. (1977) Sociology in the Balance. (Oxford: Blackwell).

Gulbrandsen, L. and Moe, A. (2007). 'BP in Azerbaijan: A Test Case of the Potential and Limits of the CSR Agenda'. Third World Quarterly, 28(4): 813-830.

Guzman, F. and Becker-Olsen, K. (2010) 'Strategic corporate social responsibility: A brand building tool'. In Louche et al (2010) Innovative CSR: From risk management to value creation. Sheffield: Greenleaf Publishing.

Haase, M. (2015) 'Marketing Ethics'. In Idowu et al (2015) Dictionary of Corporate Social Responsibility, Heidelberg: Springer.

Hopkins, M. (2007) Corporate Social Responsibility and International Development. London: Earthscan.

Idemudia, U. (2009) Oil Extraction and Poverty Reduction in the Niger Delta: A critical examination of partnership initiatives. Journal of Business Ethics. 9091-116.

Ite, U. (2007) 'Changing Times and Strategies: Shell's contribution to sustainable community development in the Niger Delta, Nigeria'. Sustainable Development, 15(1): 1-14.

Khan, F.R., R. Westwood and D.M. Boje (2010). 'I feel like a foreign agent': NGOs and corporate social responsibility interventions into Third World child labour', Human Relations, $\mathrm{XX}(\mathrm{X})$ : 1-22.

Lauwo, S. and Otusanya, O. (2014) 'Towards a political economy perspective on CSR in a developing country context: A case study of Tanzania'. In Idowu et al People, Planet and Profit: Socio-Economic Perspectives of CSR. Farnham: Gower Publishing.

Mamdani, M. (1996) Citizen and Subject: Contemporary Africa and the Legacy of Late Colonialism, Princeton: Princeton University Press.

Maon, F., Lindgreen, A. and Swaen, V. (2010) "Organizational stages and cultural phases: a critical review and a consolidation model of corporate social responsibility development", International Journal of Management Reviews, 12(1): 20-38.

Memmi, A. (1965) The Colonizer and the Colonized. Boston: Beacon Press.

Memmi, A. (1968) Dominated Man: Notes towards a portrait. Orion Press.

Merton, R.K. 1967. Social Theory and Social Structure. New York: The Free Press

Munshi, D. and Kurian, P. (2007) The Case of the Subaltern Public: A postcolonial look at public relations, greenwashing and the separation of public', Public Relations Review, 31(4): 513-520.

Nan, X. and Heo, K. (2007) 'Consumer responses to corporate social responsibility initiatives: Examining the role of brand-cause fit in cause-related marketing', Journal of Advertising, 36(2): 63-74. 
Nielsen, M. (2015) 'Advertising and Corporate Social Responsibility'. In Idowu et al (2015) Dictionary of Corporate Social Responsibility, Heidelberg: Springer.

Olsen, G. et al (2003) 'When profit equals price: Consumer confusion about donation amounts in cause-related marketing. Journal of Public Policy and Marketing. 22(2): 170-180. Omeje, K. (2006). Petrobusiness and Security Threats in the Niger Delta, Nigeria. Current Sociology. 54(3): 477-99.

Pfau et al 2008) 'The influence of corporate social responsibility campaigns on public opinion. Corporate Reputation Review 11(2): 145-154.

Prieto- Carron, M., Lund-Thomsen, P., Chan, A. Muro, A. and Bhushan, C. (2006) 'Critical Perspectives on CSR and Development: what we know, what we don't know and what we need to know', International Affairs, 82(5): 977-987.

Roberts, J. (2006). 'Beyond Rhetoric: Making a reality of corporate social responsibility' in Allouche, J. (ed.) Corporate Social Responsibility: Concepts, accountability and reporting, Basingstoke, Palgrave.

Robinson, A. and Tormey, S. (2009) "Resisting 'Global Justice': disrupting the colonial 'emancipatory' logic of the West", Third World Quarterly, 30(8): 1395-1409.

Rwabizambuga, A. (2007) 'Negotiating Corporate Social Responsibility Policies and Practices in Developing Countries: An Examination of the Experiences from the Nigerian Oil Sector'. Business and Society Review. 112(3): 407-430.

Sachs, W. (ed) (1992) The Development Dictionary. London: Zed Books.

Said, E. (1994) Culture and Imperialism. New York: Vintage Books.

Said, E. (1995) Orientalism. London: Penguin.

Shiva, V. (1988) Staying Alive: Women, ecology and development. London: Zed Books. Simon, D. (1998) "Rethinking (post)modernism, postcolonialism and post-traditionalism: South-North perspectives," Environment and Planning: Society and Space, 16: 219-245 Toker, H. (2015) 'Public relations and finance'. In Idowu et al (2015) Dictionary of Corporate Social Responsibility, Heidelberg: Springer.

Tuodolo, F. (2009) 'Corporate Social Responsibility: Between Civil Society and the Oil Industry in the Developing World, ACME: An International E-Journal for Critical Geographies. 8(3): 530-541.

Utting, P. and Marques, J.C (2009) 'Introduction: The Intellectual Crisis of CSR'. In Utting, P. and Marques, J.C. (eds) Corporate Social Responsibility and Regulatory Governance. Basingstoke: Palgrave.

Webb, D. and Mohr, L. (1998) 'A typology of consumer responses to cause-related marketing: From skeptics to socially concerned '. Journal of Public Policy and Marketing. 17(2): 226-238. 